\title{
Effective Watershed Management: Planning, Implementation, and Evaluation
}

\section{Mingxin Guo}

Department of Agriculture and Natural Resources, Delaware State University, USA

*Corresponding author: Mingxin Guo, Department of Agriculture and Natural Resources, Delaware State University, USA, Tel: 1-302-857-6479; Fax: 1-302-857-6455; E-mail:mguo@desu.edu

Rec date: Oct 24, 2014, Acc date: Oct 24, 2014, Pub date: Oct 31, 2014

Copyright: (c) 2014 Guo M. This is an open-access article distributed under the terms of the Creative Commons Attribution License, which permits unrestricted use, distribution, and reproduction in any medium, provided the original author and source are credited.

\section{Editorial}

A watershed is a basin-like land area that captures rainfall and conveys the overland flow and subsurface drainage water to an outlet in the main flow channel. It is a geo-hydrological unit comprising land, water, and biota within the confines of a drainage divide [1]. The boundary of a watershed follows the highest ridgeline around the within stream channels and meets at the bottom of the land where water flows out of the watershed (Figure 1). Watersheds vary in size and shape. A large watershed can cross county, state, and even national boundaries. Within a large watershed, there may be a number of subwatersheds. In the continental U.S.A, there are a total of 2,110 top-tier watersheds [2], with Mississippi River Watershed the largest one covering 1,200,000 square miles and supporting 70 million people [3]. The Mississippi River Watershed consists of many sub-watersheds such as the Arkansas River Watershed, the Ohio River Watershed, and the Missouri River Watershed. Within each of the sub-watersheds, numerous lower-tier watersheds are nested.

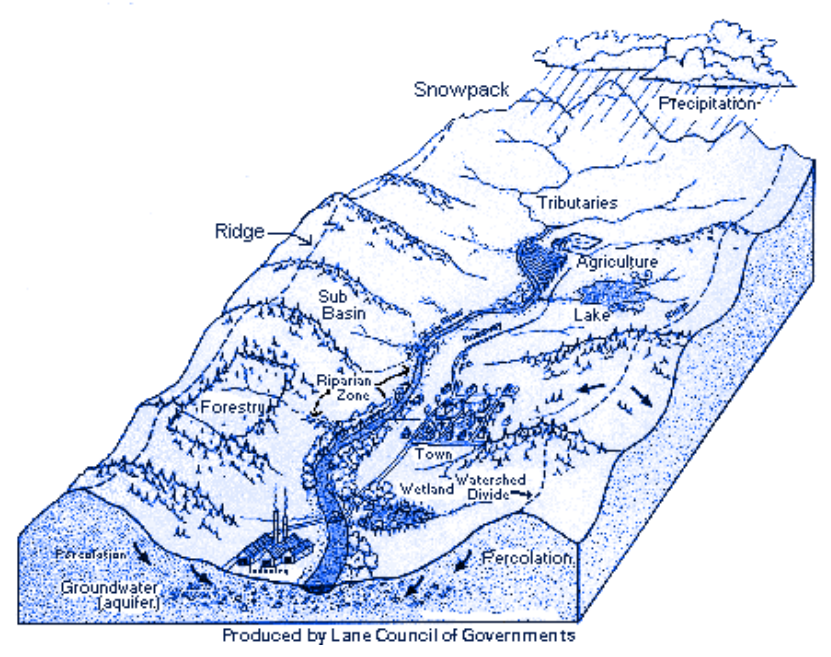

Figure 1: A watershed sketch [2]

Watersheds collect rainfall water, store it in soil and land depressions, and circulate it via various hydrological processes. A healthy watershed serves as the water supply source and provides wildlife-harboring, scenic, recreational and historic values. Human and wildlife inhabitants obtain clean freshwater predominantly from the local watersheds that receive and convey natural precipitation. The quality of water may change during transport and human utilization in the watershed. While soil filtration typically purifies water, waste discharges from human activities can contaminate water. Adequate supply of uncontaminated freshwater to meet agricultural, industrial, commercial, and domestic requirements relies on effective management of the limited water resource at the watershed scale. To wisely allocate, use, and protect the water resource in a watershed, scientific planning and successful implementation of water management practices based on particular characteristics of the watershed are essential. The management practices should be regularly evaluated and adjusted to comply with the changing circumstances and to achieve best socioeconomic and environmental benefits.

A watershed is unique blends of climate, geology, hydrology, soil, vegetation, and the human community. Knowing the watershed is the first step in effective watershed management. Fundamental information about a watershed include its size, boundary, topography, soil types, climate, population and density, land uses and trends, distribution of streams and lakes, water quality and quantity, water uses, and economic and social trends. Other critical knowledge extends to drinking water supplies, toxic release sites, point-source wastewater discharge sites (National Pollution Discharge Elimination System permits required), superfund sites, existing filter/buffer strips, wildlife habitat, wetlands, and riparian areas, and on-going restoration, rehabilitation and other best management practices in the watershed [4].

Effective watershed management includes planning, implementation, and evaluation components (Figure 2). Scientific planning is to characterize the present watershed conditions, identify and prioritize problems, define management objectives, and develop protection or remediation strategies and practices. A watershed management plan starts with partnership establishment with identified stakeholders who make water resource and quality management decisions, who implement or can affect implementation of the decisions, who are influenced by the decisions, and who can assist in the management planning [5]. The stakeholders will help identify issues and concerns in the watershed and set up long-term management goals. 


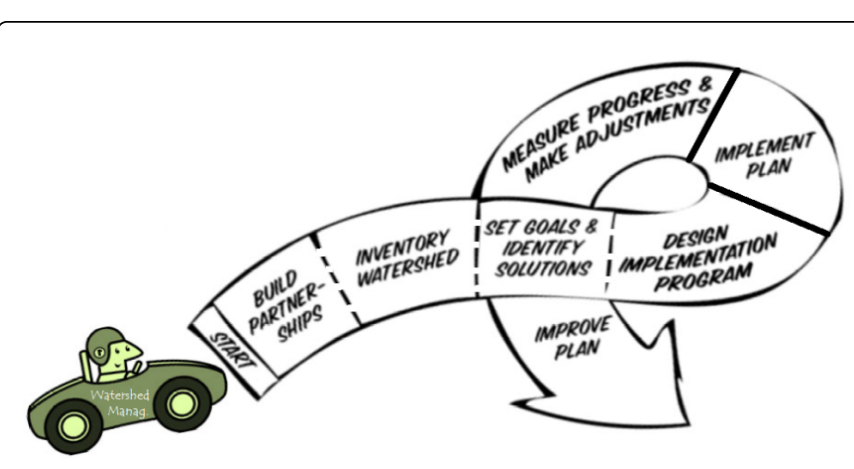

Figure 2: The cooperative and iterative watershed management steps: planning, implementation, and evaluation [5]

Characterizing watershed is the next step in management planning The whole watershed should be inventoried for its physical and natural features, land use and population characteristics, water resources and uses, water quality and water body conditions, pollutant sources and loads, and existing pollution control practices. The characterization typically reveals the most pressing water problems that the management efforts should focus on. The information is then applied to refine the overall management goals, develop specific objectives, and determine measurable targets and indicators. Subsequently, effective management practices for reducing pollution, restoring damaged ecosystems, protecting valuable habitat, and improving overall watershed health are identified based on scientific research results. The required technical and financial assistance and the needed authorities for installing the practices should be considered. If pollutant load reductions are decided to meet the management goals and water quality targets, it is necessary to understand the cause-and-effect relationship between pollutant loads and the water body response. Total Maximum Daily Load (TMDL) regulations may be imposed to limit "the maximum amount of a pollutant that a water body can receive from both point and nonpoint sources and still meet water quality standards" [5]. Approaches for reducing pollutant loads to the desired extents can be evaluated using available models.

How to implement the management plan comes to the final yet most critical stage in watershed management planning. A schedule showing trackable timelines, staged accomplishments, specific tasks, and the responsible agencies needs to be developed. The schedule should incorporate the potential impacts of weather and seasonal factors on implementation of the field projects. It is also important to establish short-term (1-2 yrs), mid-term (2-5 yrs), and long-term (5-10 yrs) milestones that help measure the implementation of activities in the management plan. An estimate of the date on which the pre-set water quality standards will be reached through the proposed actions increases the credibility of the management plan. Benchmarks to measure progress toward the management goals needs to be defined. The benchmarks can be direct water quality measurements (e.g., turbidity, dissolved oxygen content, and concentrations of chlorophyll a, fecal coliform and nutrients) or indirect indicators of load reduction (e.g., length of stream corridor revegetated, volume of trash removed, and number of beach closings). A monitoring program including preproject (baseline), during-project (active), and post-project (after) monitoring should be designed accordingly to obtain data of the benchmarks [4]. It is necessary to include backup options (e.g., changing management practices, re-evaluating source areas, updating loading analyses, reassessing water quality response time) for situations that the interim targets are not met and the management plan needs to be revised. An evaluation plan with quantitative indicators to measure the inputs (e.g., stakeholder involvement, time, materials, and resources of technical expertise and financial support), outputs (e.g., installed management practices), and outcomes (e.g., water quality improvements, pollutant load reductions, and habitat restoration) of the watershed implementation program is obligatory.

Implementing a watershed management plan involves various expertise and skills such as technical expertise, group facilitation, project management, data analysis, communication, and public relations. Successful implementation requires first to secure the entailed technical and financial assistance. It is vital to transfer the ownership of the watershed management plan to local governments. Dedicated professionals and administrative staff who are supported by local governments are the critical workforce for organizing implementation efforts, coordinating, and carrying out the management tasks. Open communication between organization members and increased involvement of stakeholders are equally important. Progress should be constantly tracked in project implementation, maintenance activities, water quality improvements, and social responses. It is critical to install a watershed health monitoring program to evaluate the effectiveness of the implementation efforts. Water conditions can be monitored by measuring water flow and color, streambank conditions, aquatic organism abundance, and concentrations of contaminants in water, sediments, and fish tissue [5]. The monitoring data should be timely analyzed to examine status, changes, trends, or other issues of watershed health that responds to management practices. Routine summary analyses should also be conducted to track progress, assesses achievements of objectives, and provide early feedback on watershed health changes and trends. Sharing the results with stakeholders and other communities via communication (in reports, meetings, and education activities) is important. The outreach efforts help to keep the stakeholders engaged by showing them how their participation is making a difference.

Evaluation during and after implementation of conservation practices are an indispensable component of watershed management. The implementation activities need to be periodically reviewed and compared with those outlined in the work plan. The implementation results collected through monitoring programs need to be parallel with the interim milestones. If the implemented practices are not adequately effective such that the milestones and targets set for pollutant load reductions and other goals are not met, implementation adjustments and/or additional management measures become necessary. Feasibility for making the required implementation changes should be assessed prior to action. As a rule, progress on the work plan, watershed health improvements, and any necessary adjustments in implementation should be made known to stakeholders [5]. Feedbacks from landowners and other stakeholders should be integrated in implementation adjustments.

The natural resources in a watershed are generally owned by many proprietors and used for multiple, conflicting purposes. Coordinating all users' interest in watershed management is truly a challenge. Individuals who lead collaborative watershed partnerships must cope with both complex environmental issues and multifaceted coordination tasks [6]. Social organization and participation can weigh heavier than technology in watershed approaches [7]. Research can develop best management practices for improving watershed health, 
Citation: Guo M (2014) Effective Watershed Management: Planning, Implementation, and Evaluation . Hydrol Current Res 5: e119. doi:

Page 3 of 3

but the disproportionate efforts involved in formation and maintenance of a new institution are rather discouraging.

Collaborative, collective, and integrated approaches are desperately needed to effectively manage top-tier watersheds that cover different counties and states. Although the affected local governments should be included in the partnership institution, an overriding executive organization has to be formed with authority granted from the higherlevel government (e.g., a federal agency). The organization is able to minimize local political impacts and efficiently define boundaries of the watershed, make decisions, and reinforce the accountability of the program [8]. The organization can be hierarchic, with divisions in charge of different sub-watersheds. A master management plan integrating science with social, economic, ecological and policy concerns from the entire watershed should be developed, properly controlling water uses and pollutant loads of individual subwatersheds [9]. In each sub-watershed, a specific management plan is implemented to achieve the water quality and eco-health goals set for the sub-watershed by the master plan. Such hierarchic systems realize the vitality of coordination and integrity in large watershed management and in the meanwhile, practice participatory approaches centering on local solidarity at the sub-watershed level [10]. For example, the Mississippi River/Gulf of Mexico Watershed Nutrient Task Force was established in 1997 to reduce and control water eutrophication in the Gulf of Mexico from nutrients introduced by the Mississippi River. The task force consists of 6 sub-basin committees and includes 5 federal agencies, 12 states and the tribes within the Mississippi/Atchafalaya River Basin [11]. Action plans have been developed and best management practices implemented through the task force's movement. The task force also holds regular meetings to inform the public of the progress made and solicit comments from the public.

\section{References}

1. USDA (2007) Watersheds, hydrologic units, hydrologic unit codes, watershed approach, and rapid watershed assessments Natural Resource Conservation Service, United States Department of Agriculture: Washington, D.C.

2. EPA (2012) What is a watershed?. Environmental Protection Agency: Washington, D.C.

3. NPS (2014) Mississippi River facts. National Park Service: St. Paul, MN.

4. CTIC (2014) Getting to know your local watershed. Conservation Technology Information Center: West Lafayette, IN.

5. EPA (2013) A Quick Guide to Developing Watershed Plans to Restore and Protect Our Waters. EPA 841-R-13-003. U.S. Environmental Protection Agency: Washington, D.C.

6. Blomquist W, Schlager E (2005) Political pitfalls of integrated watershed management. Society \& Natural Resources: An International Journal 18:101-117.

7. Kerr J (2007) Watershed management: Lessons from common property theory. Int. J Commons 1: 89-110.

8. Bonnell SE, Koontz TM (2007) Stumbling forward: The organizational challenges of building and sustaining collaborative watershed management. Society \& Natural Resources: An International Journal 20:153-167.

9. de Steiguer JE, Duberstein J, Lopes V (2003) The analytic hierarchy process as a means for integrated watershed management. 736-740.

10. Baril P, Maranda Y, Baudrand J (2006) Integrated watershed management in Quebec (Canada): a participatory approach centred on local solidarity. Water Sci Technol 53: 301-307.

11. EPA (2014) Mississippi River/Gulf of Mexico Watershed Nutrient Task Force. U.S. Environmental Protection Agency: Washington, D.C. 